\title{
Validation of The Environmental Kuznets Curve Hypothesis And Role of Carbon Emission Policies In The Case of Russian Federation
}

Nurcan Kilinc-Ata ( $\nabla$ nurcankilinc@yahoo.com )

National Research University Higher School of Economics https://orcid.org/0000-0001-8780-1983 Vladimir L. Likhachev

National Research University Higher School of Economics

\section{Research Article}

Keywords: Environmental Kuznets Curve, carbon emission, economic growth, energy consumption, population, trade openness, financial development.

Posted Date: February 9th, 2022

DOI: https://doi.org/10.21203/rs.3.rs-1279598/v1

License: (c) (i) This work is licensed under a Creative Commons Attribution 4.0 International License.

Read Full License 
Validation of the Environmental Kuznets Curve Hypothesis and Role of Carbon Emission Policies in the Case of Russian Federation

\begin{abstract}
Climate change currently observed and expected in the future is associated with risks to security and sustainable development as well as natural and irreversible consequences. To minimize these risks, it is necessary to adapt the public administration, economic sectors, and regional infrastructure to the changing climate conditions. This paper discovers the links between $\mathrm{CO}_{2}$ emission and their key determinants such as economic growth, energy consumption, population, trade openness, and financial development for the Russian Federation using data from 1990 through 2020. Findings reveal that energy consumption, and population have a positive impact on $\mathrm{CO}_{2}$ emissions, while economic growth, financial development, and trade openness has been found to decrease $\mathrm{CO}_{2}$ emissions in the long term. The results of the paper show that there is a "U" shaped relationship between $\mathrm{CO}_{2}$ emissions and economic growth in the Russian Federation. This shows that EKC is valid up to a certain income level in the Russian Federation and when this income level is exceeded, a positive relationship will begin between economic growth and environmental degradation.
\end{abstract}

Keywords: Environmental Kuznets Curve, carbon emission, economic growth, energy consumption, population, trade openness, financial development.

\title{
1. Introduction
}

With the start of the industrial revolution, technological developments accelerated and investments increased and a growth in the income levels of the countries was observed. However, as a result of increasing energy use -especially the consumption of fossil fuels- environmental changes and degradations has started. Since the primary goal of the countries is economic growth and development, the negativities that have arisen have been ignored. Conversely, rising worldwide warming and ecological pollution in the 1960s expose the significance of this topic and principal to the questioning of the relationship between economy and ecological pollution (Balado-Naves, et al. 2018: 266). Furthermore, energy is a strong input for enabling economic growth but it also exerts adverse environmental consequences. 
35 However, the use of renewable and clean energy resources is often linked with environmental improvement while fossil fuel consumption is usually alleged to hamper environmental well-being (Kanat, 2021: 2).

Russian Federation is the fourth country to contribute to carbon dioxide $\left(\mathrm{CO}_{2}\right)$ emissions the entire world, after China, the United States (US), and India, respectively, although Russian Federation has signed the Kyoto Protocol and adopted the Paris Agreement (Ketenci, 2018: 250). In 2020, $\mathrm{CO}_{2}$ emissions in Russian Federation amounted to approximately 1.48 billion metric tons of $\mathrm{CO}_{2}$, making a decrease relative to the previous year but emissions of the Russian Federation are expected to continue rising until 2030 due to the geographical location and the characteristics of the climate and fossil fuels still make up $90 \%$ of Russian Federation energy mix (e.g. power, heat, transport, etc.). Russian Federation's emissions dropped by $41 \%$ between 1990 and 1998 but increased by 15\% between 1998 and 2017 (Climate Transparency, 2020). The carbon zero target of the Russian Federation is 2060.

$\mathrm{CO}_{2}$ emissions have been extensively studied at national and regional scales, and most research emphases on the link between $\mathrm{CO}_{2}$ emissions and possible impact factors, including economic growth, population, energy consumption, energy intensity, and industrial structures. While some researchers have studied national groups such as Gulf Cooperation Council (GCC) countries (Ansari et al. 2020; Alsamara et al. 2018; Beck and Joshi, 2015; Salahuddin and Gow, 2014), Organization for Economic Cooperation and Development (OECD) countries (Isik et al. 2021; Leal and Marques, 2020; Iwata et al. 2012) and the Middle East and North Africa (MENA) countries (Cheikh et al. 2021; Gorus and Aslan, 2019; Abdallh and Abugamos, 2017; Al-Rawashdeh et al. 2014) and so on. Some researchers also have investigated a specific country. Conversely, the link between economic growth and greenhouse gas emissions in Russian Federation has rarely been studied. Russian Federation is rich in natural resources, which has made Russian Federation a typical resource-based economy country. In addition, there is a conflict between the Russian Federation's economic development and greenhouse gas emission reduction (Yang, et al. 2017: 163). Therefore, examining the relationship between greenhouse gas emissions related to the economy and Gross Domestic Product (GDP) in Russian Federation has important implications both in theory and in practice. 
The presented study aims to investigate empirically factors (population, GDP per capita, energy consumption, trade openness, and financial development) affecting

$70 \mathrm{CO}_{2}$ emissions per capita in the Russian Federation during the period of 1990-2020.

71 Furthermore, this paper scrutinizes validation of the Environmental Kuznets Curve 72 (EKC) hypothesis for the Russian Federation that contributes to $\mathrm{CO}_{2}$ emission 73 policies.

The contribution of the present paper to the previous literature is manifold.

75 Firstly, this study is the first attempt, to the best of our knowledge, that analyse the validity of the EKC hypothesis for a selected long-term dataset time interval (covering the period 1990-2020) and various data Russian Federation. Second, existing studies on Russian Federation largely look at the $\mathrm{CO}_{2}$ emission impact of economic growth and energy consumption, the current paper also includes trade openness and financial development variables which are important in developing countries. Third, the current paper includes more recent and up-to-date observations compared to previous studies in the literature.

The rest of the present study is as follows: The following section assessments empirical papers in the literature. The third section presents the methods applied in the paper and empirical results are outlined as well. The discussion and conclusion on policy implications are performed in the following part.

\section{Literature Review}

The reduction in emissions is explained by several of factors, such as changes in household consumption, the effectiveness of environmental policies, and important changes in the economy resulting from technological modernization (Gavrilyeva et al. 2020). Therefore, the relationship between a nation's economic development and its $\mathrm{CO}_{2}$ emissions is regarded as empirically significant. There are several methods to scrutinize the link between economic growth and $\mathrm{CO}_{2}$. The $\mathrm{EKC}$ model, which is one of these methods, is well developed and widely used in investigating the economyemissions relationship (Youssef et al. 2020; Brown and McDonough, 2016; Yang et al. 2015). In this study, unlike other studies, the EKC hypothesis was verified with more specific and extensive data, and the findings were compared with the EKC studies in the literature.

Generally, research shows that the inverse U-shaped link between economic 101 growth and $\mathrm{CO}_{2}$ is valid. From recent studies, Salari et al. (2021) assess the link 
between $\mathrm{CO}_{2}$ emissions, energy consumption, and economic growth GDP at the state level in the US between 1997 and 2016. The findings show an inverted U-shaped link between $\mathrm{CO}_{2}$ emissions and GDP, providing sufficient evidence to confirm the EKC hypothesis across states. Similarly, AlZgool et al. (2020) display that the EKC hypothesis is effective for Bahrain as there is a encouraging link between economic growth and $\mathrm{CO}_{2}$ emissions and the square of economic growth has a adverse impact on $\mathrm{CO}_{2}$ emissions.

The EKC test for various countries and regions shows that this hypothesis is not always valid. To a large extent, this is determined by the length of time intervals analyzed and by national and regional characteristics (Friedl and Getzner, 2003). For example, Lantz and Feng (2006) calculations over 30 years (1970-2000) revealed no correlation between emissions and GDP for the five Canadian regions. Similarly, Baek (2015) discovered that the EKC hypothesis was not acceptable for Arctic countries between 1960 and 2010. Economic growth only has a beneficial effect on the environment in some Arctic countries. Finally, energy consumption has been discovered to have a negative impact on $\mathrm{CO}_{2}$ emissions in most countries.

In Russian Federation, where the link between economic growth and greenhouse gas emissions is rarely examined, some studies found the EKC hypothesis valid, while others found it invalid. Of the studies that specifically investigated Russian Federation, Yang, et al. (2017) tested the inverted U-shaped link between GDP per capita and greenhouse gas emissions linked to the economy per capita. The findings encouraged the EKC hypothesis for Russian Federation. This result is also supported by Burakov (2019); Bass et al. (2019); Ketenci (2018); Rudenko and Skripnuk (2016), their results are coherent with the EKC hypothesis and valid for Russian Federation. Differently, Pao et al. (2011) analysed the inverse U-shaped relationship between $\mathrm{CO}_{2}$ emissions, energy consumption, and economic growth in Russian Federation from 1990 to 2007 and found that $\mathrm{CO}_{2}$ emissions decrease as GDP increases when energy consumption is adjusted, and the EKC hypothesis is not acceptable for Russian Federation. This idea is supported by Rustemoglu and Andrés (2016) in their study by investigating Russian Federation and Brazil, they indicated that changes in $\mathrm{CO}_{2}$ emissions from 1992 to 2011 in Russian Federation were affected by economic activities, but a decoupling also emerged between GDP and $\mathrm{CO}_{2}$ emissions. 


\section{Data and Method}

\subsection{Data}

In this paper, the acceptability of the EKC hypothesis in the Russian

142 Federation was investigated for the years 1990-2020 by tested with the time series

143 analysis method within the scope of the EKC hypothesis. At this point, we would like

144 to emphasize that with the disintegration of the Union of Soviet Socialist Republics 145 (USSR) in 1991, the Russian Federation economy began a radical transformation. For 146 the Russian Federation economy, which experienced an acute financial crisis in 1998, 147 serious economic reforms have been made since the 2000s (Shumkov, 2010).

148 The variables used for analysis, as well as their definition, unit of 149 measurement and sources are presented in Table 1 and all variables are stated in 150 natural logs.

151 Table 1: Description of the Variables Used for Analysis

\begin{tabular}{|l|l|l|l|}
\hline Variables & Definition & Unit of measurement & Sources \\
\hline $\mathrm{CO}_{2}$ & $\begin{array}{l}\text { Carbon Dioxide Emission per } \\
\text { capita }\end{array}$ & Tons $\mathrm{CO}_{2}$ per capita & IEA \\
\hline GDP & $\begin{array}{l}\text { Gross Domestic Product per } \\
\text { capita }\end{array}$ & $\begin{array}{l}\text { PPP current } \\
\text { international US\$ }\end{array}$ & World Bank \\
\hline EC & Energy consumption & Kilowatt-hours & World Bank \\
\hline TO & Trade openness & BoP, current US\$ & World Bank \\
\hline FD & Financial development index & Percentage (index) & IMF \\
\hline POP & Population & Million & Statista \\
\hline
\end{tabular}

154 sources such as oil, natural gas, and coal gas measured tons per capita. GDP is the log 155 of the GDP measured in per capita as an indicator of economic development. 156 Similarly, GDP ${ }^{2}$ is the log of the square of the GDP measured in PPP (Purchase 157 Power Parity) current international dollar.

158 EC is the log of total energy consumption measured in per capita kilowatt159 hours. EC variable includes oil, coal, gas, renewable energy, and nuclear power 160 generation. When the literature is reviewed, many studies certainly prefer the data of 161 energy consumption to strengthen the EKC model (Amri, 2018; Shahbaz et al. 162 2013a), since a large proportion of total energy consumption is composed of fossil 163 fuels, and its inclusion is not surprising given the obvious harmful effects of fossil 
164 fuels on the environment. Furthermore, some obstacles are effective in the high $\mathrm{CO}_{2}$ 165 emission due to the presence and excess of energy consumption, especially fossil166 based energy sources. For instance, the fact that weather conditions in Russian 167 Federation are incomparable to many countries (e.g. many USA states and EU 168 countries, Turkey) and the low air temperature is increases the energy consumption 169 (Cruz Rios et al. 2017). In addition, Russian Federation ranks first in the world's 170 natural gas reserves (Marshintsev and Gadiyatov, 2021) and therefore natural gas use 171 in the country is cheap. This is another important obstacle to the transition to zero $172 \mathrm{CO}_{2}$ emission renewable energy sources.

173 TO is the log of the sum of export and imports of total goods and services as 174 an indicator of the trade openness, which measures the balance of payment (BoP) in 175 the current US dollar. Grossman and Krueger (1991) discuss that trade openness is 176 linked to three main thoughts. These are scale effect, composition effect, and 177 technical effect. The first two effects would be anticipated to have adverse impact on 178 the environment in a developing country. The technical impact is assumed to 179 contribute to the protection of the environment. The comparison of trade openness 180 with the countries (China, Netherlands, and United Kingdom (UK)) to which the 181 Russian Federation exports the most in 2020 is as in Figure 1 below.

182

183 Figure 1: Trade Openness: Export Plus Imports as Percent of GDP

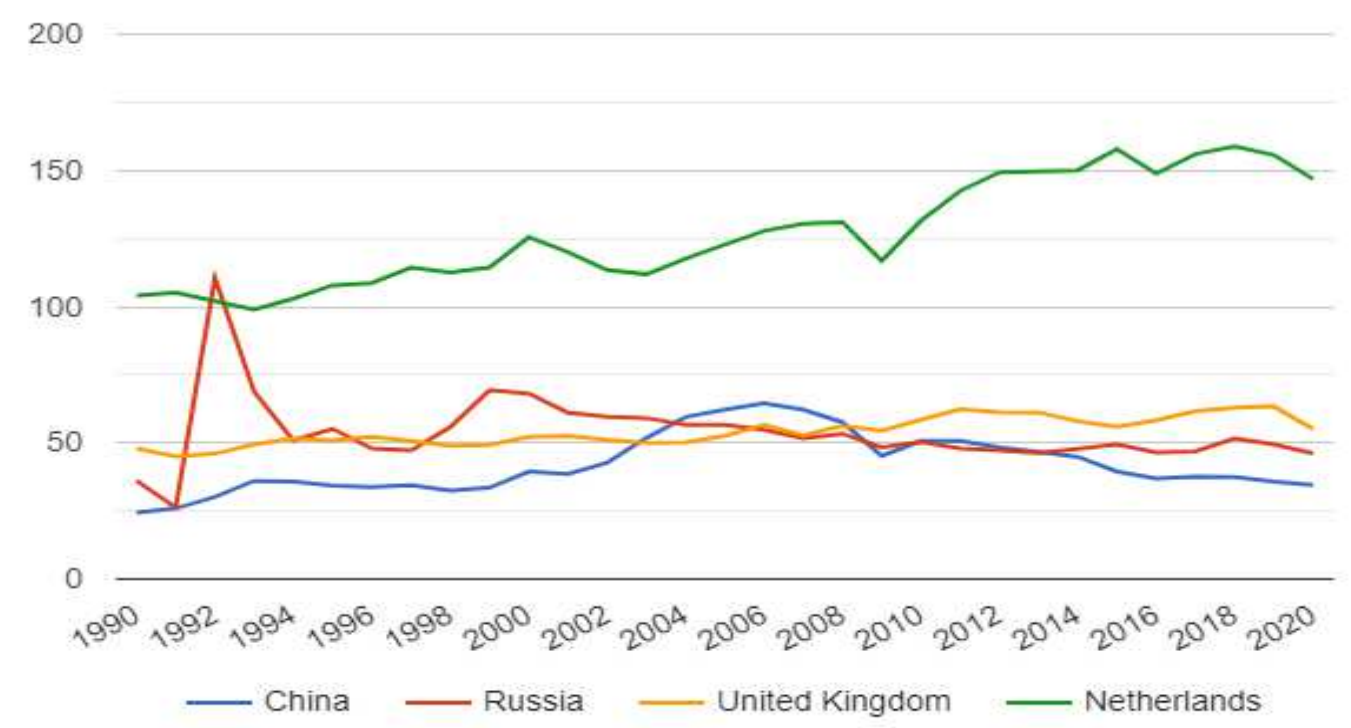

185 Source: World Bank, (2021), https://www.theglobaleconomy.com/compare-countries/, Access Date: 
As seen in Figure 1, the trade openness of China, the Russian Federation, and the UK is very similar and close, while the trade openness of the Netherlands is different from these countries. The reason for including trade openness in our variables is to reveal that trade openness increases or decreases environmental 192 pollution for the Russian Federation. For example, Aydın and Turan (2020) find in 193 their study that trade openness reduces environmental pollution in China and India, 194 and increases it in South Africa. Conversely, Jalil and Feridun (2011) discover that 195 trade openness has an increasing effect on $\mathrm{CO}_{2}$ emissions for China. Similarly, 196 Farhani and Ozturk, (2015) obtain that a $1 \%$ increase in trade openness raises $\mathrm{CO}_{2}$ emissions by $0.418 \%$ in the long term for Tunisia.

198 FD is financial development measure and analyses the factors enabling the 199 development of the financial system. To represent which financial development, the 200 financial development index created by Svirydzenka (2016) within the International 201 Monetary Fund was used. Financial development can have various effects on $\mathrm{CO}_{2}$ emissions. Primary, there is evidence in the literature that financial development promotes to economic growth by increasing foreign direct investment (FDI) (Nasir et al. 2019) and improving the equity and credit market (Hsu et al. 2014), which means easier access to credit for stockholders and customers (Zhang 2011). Higher economic growth needs more energy consumption and can contribute to $\mathrm{CO}_{2}$ emissions (Pao and Tsai, 2011). Also, financial development can support companies' access the more

208 funds to invest in ecologically friendly technologies and projects that reduce $\mathrm{CO}_{2}$ emissions (Shahbaz et al. 2013b). For Russian Federation, Haseeb et al. (2018) find that financial development plays a significant role in decreasing the level of $\mathrm{CO}_{2}$

211 emissions in Russian Federation. Similarly, Bass (2019) finds that the financial sector 212 is an essential factor of $\mathrm{CO}_{2}$ emissions in the Russian Federation. Therefore, including 213 the financial development data in the model is essential to increase the validity of the 214 EKC hypothesis for the Russian Federation. Furthermore, we would also like to 215 emphasize that Russian Federation has never been a popular Financial Direct 216 Investment (FDI) destination by western countries. The latest data show that FDI 217 flows into Russian Federation decreased from \$32 billion in 2019 to \$10 billion in 2182020 with down $70 \%$, and this has had an influence on the Covid-19 pandemic as well 219 (UNCTAD World Investment Report, 2021).

220 POP is the $\log$ of the population measured in millions. Studies on population 221 growth and EKC emphasize that population growth shifts the EKC curve upward, 
causing deforestation, and that the negative environmental impact is greater with population growth (Wang et al. 2015; Culas, 2007).

Largely, previous studies testing the EKC hypothesis have used only pollutant emissions, economic development, and energy consumption (Jun et al. 2021; Yusuf et al. 2020; Zhang et al. 2019; Alege et al. 2016; Ozcan, 2013; Pao and Tsai, 2010), while some studies have considered new variables such as electricity consumption (Saint Akadiri et al. 2020; Cowan et al. 2014; Akpan and Akpan, 2012), trade openness (Koc and Bulus, 2020; Mahmood et al. 2019; Ozatac et al. 2017), financial development (Amri, 2018; Jamel and Maktouf, 2017; Shahbaz et al. 2013a), renewable/non-renewable energy/electricity production (Chen et al. 2019; Bento and Moutinho, 2016), oil prices (Erdogan et al. 2020; Balaguer and Cantavella, 2016), population (Liu et al. 2015; Begum et al. 2015), urbanization (Salim et al. 2019; Hanif, 2018; Pata, 2018), and corruption (Balsalobre-Lorente, 2019; Sekrafi and Sghaier, 2018).

\subsection{Method}

The EKC hypothesis suggests that ecological pollution growth in the initial periods of economic development. According to the EKC hypothesis, it assumes that as the welfare level of a country increases, environmental pollution will increase and after a certain income, income increase will contribute positively to environmental quality (Karaca, 2012: 143). The current study scrutinizes the link between ecological pollution and economic development in Russian Federation including the period from 1990-2020 and the basic EKC hypothesis is formulated as follows Equation (1):

$$
C O_{2 t}=f\left(G D P_{t}, G D P_{t}^{2}, E C_{t}, T O_{t}, F D_{t}, P O P_{t}\right)
$$

In Equation (1), $\mathrm{CO}_{2 t}$ states the $\mathrm{CO}_{2}$ emission per capita, $G D P_{t}$, and $G D P_{t}^{2}$ states GDP per capita and its square, respectively. $E C_{t}$ states energy consumption, $T O_{t}$ states trade openness, $F D_{t}$ states financial development and $P O P_{t}$ indicates population. All data used in the study are at the annual frequency and all are included in the analysis in logarithmic form. Thus, the log linear-quadratic model formulated is shows in Equation (2).

$$
\operatorname{InCO} 2 t=\beta_{0}+\beta_{1} \operatorname{InGDP} P_{t}+\beta_{2} \operatorname{In}\left(G D P_{t}^{2}\right)+\beta_{3} \operatorname{InEC} C_{t}+\beta_{4} \operatorname{InTO} O_{t}+\beta_{5} \operatorname{InFD} t
$$

$$
\beta_{6} \operatorname{InPOP} P_{t}+\varepsilon_{t}
$$


According to Equation (2), $\mathrm{t}$ denotes time and means that the natural logarithm of the relevant variable is taken. The possible results of the model expressed in Equation 2 within the scope of EKC are as follows (Dinda, 2004: 431).

I. $\beta_{1}=\beta_{2}=0$, There is no link between $\mathrm{CO}_{2}$ and income.

II. $\quad \beta_{1}>0$ and $\beta_{2}=0$, The link between $\mathrm{CO}_{2}$ and income is linear.

III. $\beta_{1}<0$ and $\beta_{2}=0$, The link between $\mathrm{CO}_{2}$ and income is negative.

IV. $\beta_{1}>0$ and $\beta_{2}<0$, The link between $\mathrm{CO}_{2}$ and income is "inverted $U$ " and the $\mathrm{EKC}$ is acceptable.

For the EKC to be valid, there must be an "inverted $\mathrm{U}$ " link between $\mathrm{CO}_{2}$ and economic growth (Allard et al. 2018: 5848). When the EKC hypothesis is approved, the turning point in which environmental pollution decreases, the level of GDP per capita, $G D P^{*}=-\beta_{1} / 2 \beta_{2}$ and the turning point is the monetary value representing that point. However, Iwata et al. (2012) argued that the turning points of developing countries can be outside the sample period and that environmental pollution continues to increase with economic growth in developing countries.

Cointegration tests are performed to examine the long-term relationship between the variables. For cointegration, the Engle and Granger (1987), Johansen and Juselius (1990) tests are pioneering and frequently used. However, an important limitation of these tests is that the variables must be equally stationary. Therefore, this paper was conducted by Pesaran et al. (2001) ARDL bounds test approach has been applied and this approach allows to determine the cointegration relationship between variables with different levels of stationarity. The ARDL bounds test was performed using Equation (3), which shows the unbounded error correction model (UECM) by applying the Wald test.

$$
\begin{gathered}
\Delta \operatorname{InCO}_{2 \mathrm{t}}=\beta_{0}+\sum_{i=1}^{a} \beta_{1 i} \Delta \operatorname{In} C O_{2 t-i}+\sum_{i=0}^{b} \beta_{2 i} \Delta \operatorname{InGDP}_{\mathrm{t}-\mathrm{i}}+ \\
\sum_{i=0}^{c} \beta_{3 i} \Delta \operatorname{In}\left(G D P_{t-1}\right)^{2}+\sum_{i=0}^{d} \beta_{4 i} \Delta \mathrm{InEC}_{\mathrm{t}-\mathrm{i}}+\sum_{i=0}^{e} \beta_{5 \mathrm{i}} \Delta \mathrm{InTO}_{\mathrm{t}-\mathrm{i}}+
\end{gathered}
$$

In Equation (3), $\beta_{0}$ denotes the constant term; $\Delta$ denotes the difference operator, $u_{t}$ demotes the error term, $\beta_{1} \ldots \beta_{7}$ denote the short-term coefficient, $\delta_{1} \ldots \delta_{7}$ denote long-term coefficient. The letters $\mathrm{a}, \mathrm{b}, \ldots . . \mathrm{g}$ denote the optimal lag 
lengths. The model allows the determination of separate lag lengths for each variable, and the null hypothesis $\left(H_{0}: \beta_{0}=\delta_{1}=\cdots=\delta_{7}=0\right)$ stating that there is no cointegration link between the variables and the alternative $\left(H_{0}: \beta_{0} \neq \delta_{1} \neq \cdots \neq\right.$ $\left.\delta_{7} \neq 0\right)$ is being created.

The ARDL method gives better results with small sample sizes when compared to other traditional cointegration tests (Nkoro and Uko, 2016: 63). The state of the cointegration link between the variables is interpreted by comparing the $\mathrm{F}$ test statistic with the critical values. The F statistic above the upper critical value is considered as the presence of cointegration, and the F statistic less than the lower critical value is considered as an indication of the absence of cointegration. The shortterm dynamics are determined by Equation (4), which is established after the determination of the cointegration relationship: the error correction process proceeds in the form of decreasing fluctuations around the long-term balance. If the coefficient is positive or greater than -2 , it indicates that the equilibrium has been moved away (Alam and Quazi, 2003: 97; Narayan and Smyth, 2006: 335). Lastly, the stability of the model was checked operating the CUSUM and

In Equation (4), $\lambda_{0}$ represents the constant term, $\lambda_{1} \ldots \lambda_{7}$ represents the shortterm coefficient; $\tau$ shows the coefficient of the error correction term (ECT). If the ECM coefficient is between 0 and -1 , there is a direct convergence to the long-term equilibrium value. If the ECM coefficient is between -1 and -2 , it is interpreted that CUSUMSQ tests suggested by Brown et al. (1975). The CUSUM and CUSUMSQ tests are suitable for time series data and can be used when it is uncertain when a structural break has occurred (Yoo, 2005: 1630).

\subsection{Empirical Findings}

Firstly, the augmented Dickey-Fuller (ADF) test developed by Dickey and Fuller (1979) and Philips Perron (PP) test is used to check the stationarity of the variables. In addition, the unit root test developed by Zivot and Andrews (2002) was 
320 used to determine the stationarity of the variables more reliably, which stated that the

321 ADF test would give more reliable results with a single internal structural break. Unit

322 root tests were applied to the level and first difference values of each variable,

323 respectively. The findings are presented in Table 2 and Table 3.

325 Table 2: ADF and PP Unit Root Test Results

\begin{tabular}{|c|c|c|c|c|c|c|c|c|}
\hline \multirow{3}{*}{$\begin{array}{l}\text { Varia } \\
\text { bles }\end{array}$} & \multicolumn{4}{|c|}{ ADF } & \multicolumn{4}{|c|}{$\mathbf{P P}$} \\
\hline & \multicolumn{2}{|c|}{$\mathbf{I}(\mathbf{0})$} & \multicolumn{2}{|c|}{ I(1) } & \multicolumn{2}{|c|}{$\mathbf{I}(\mathbf{0})$} & \multicolumn{2}{|c|}{ I(1) } \\
\hline & $\begin{array}{c}\text { Consta } \\
\text { nt }\end{array}$ & $\begin{array}{c}\text { Constan } \\
\qquad \begin{array}{c}\text { t } \\
\text { Trend }\end{array} \\
\end{array}$ & $\begin{array}{c}\text { Constan } \\
\mathbf{t}\end{array}$ & $\begin{array}{c}\text { Consta } \\
\text { nt }+ \\
\text { Trend } \\
\end{array}$ & $\begin{array}{c}\text { Consta } \\
\text { nt }\end{array}$ & $\begin{array}{c}\text { Consta } \\
\text { nt }+ \\
\text { Trend } \\
\end{array}$ & $\begin{array}{c}\text { Consta } \\
\text { nt }\end{array}$ & $\begin{array}{c}\text { Consta } \\
\text { nt }+ \\
\text { Trend } \\
\end{array}$ \\
\hline GDP & 0.4107 & $\begin{array}{c}-3.9186 \\
* *\end{array}$ & $\begin{array}{c}-2.7030 \\
* *\end{array}$ & $\begin{array}{c}-2.5984 \\
* * *\end{array}$ & -0.1417 & -2.4388 & $\begin{array}{c}-2.7030 \\
*\end{array}$ & $\begin{array}{c}-2.5984 \\
* *\end{array}$ \\
\hline GDP $^{2}$ & 0.4466 & $-3.8688 * *$ & $-2.7598 *$ & -2.6567 & -0.0961 & -2.4365 & $2.7598 *$ & -2.6567 \\
\hline EC & $\begin{array}{c}-2.9282 \\
*\end{array}$ & -2.8560 & $\begin{array}{c}-2.6426 \\
* *\end{array}$ & $\begin{array}{c}-2.6180 \\
* *\end{array}$ & $\begin{array}{c}-2.7430 \\
*\end{array}$ & -2.8560 & $\begin{array}{c}-2.6043 \\
* *\end{array}$ & $\begin{array}{c}-2.6180 \\
* *\end{array}$ \\
\hline TO & -1.8565 & -0.7233 & $\begin{array}{c}-4.7548 \\
* * *\end{array}$ & $\begin{array}{c}-5.2334 \\
* * *\end{array}$ & -2.0015 & -0.9470 & $\begin{array}{c}-4.4149 \\
* * *\end{array}$ & $\begin{array}{c}-9.6007 \\
* * *\end{array}$ \\
\hline FD & -1.6406 & -2.0084 & $\begin{array}{c}-6.0588 \\
* * *\end{array}$ & $\begin{array}{c}-5.8867 \\
* * *\end{array}$ & -1.6690 & -2.1201 & $\begin{array}{c}-6.0265 \\
* * *\end{array}$ & $\begin{array}{c}-5.8644 \\
* * *\end{array}$ \\
\hline POP & -0.2562 & $\begin{array}{c}-3.3983 \\
*\end{array}$ & $\begin{array}{c}-2.9821 \\
* *\end{array}$ & $\begin{array}{c}-2.1362 \\
* *\end{array}$ & -1.1787 & -0.9557 & $\begin{array}{c}-4.0016 \\
* * *\end{array}$ & $\begin{array}{c}-3.2565 \\
* * *\end{array}$ \\
\hline $\mathrm{CO}_{2}$ & $\begin{array}{c}-5.0405 \\
* * *\end{array}$ & $\begin{array}{c}-4.5341 \\
* * *\end{array}$ & $\begin{array}{c}-3.7833 \\
* * *\end{array}$ & $\begin{array}{c}-4.5330 \\
* * *\end{array}$ & $\begin{array}{c}-4.6747 \\
* * *\end{array}$ & $\begin{array}{c}-5.6063 \\
* * *\end{array}$ & $\begin{array}{c}-3.7316 \\
* * *\end{array}$ & $\begin{array}{c}-4.6709 \\
* * *\end{array}$ \\
\hline
\end{tabular}

326 Notes: ***, ** and * indicate 1\%, 5\% and 10\% significance levels, correspondingly.

According to the ADF and PP unit root test findings in Table 2, it is seen that

329 the variables are stationary at different degrees. It was confirmed by both unit root

330 tests that the $\mathrm{CO}_{2}$ and energy consumption variables were stationary at the level,

331 while the other variables were stationary at the first difference. Since the variables are

332 stationary at different levels, it is appropriate to use the ARDL bounds test to find

333 long-run relationships. 
Table 3: ZA Unit Root Test Results

\begin{tabular}{|c|c|c|c|c|c|c|c|}
\hline \multirow{2}{*}{ Variables } & \multicolumn{2}{|c|}{$\mathbf{I}(\mathbf{0})$} & \multicolumn{2}{|c|}{ I(1) } & \multicolumn{3}{|c|}{ Critical Value } \\
\hline & Model A & Model C & Model A & Model C & $1 \%$ & $5 \%$ & $10 \%$ \\
\hline GDP & $\begin{array}{c}-5.230483 \\
(2006)^{*}\end{array}$ & $\begin{array}{l}-6.072760 \\
(2008)^{* *}\end{array}$ & - & - & -5.34 & -4.93 & -4.58 \\
\hline GDP $^{2}$ & $\begin{array}{c}-5.230483 \\
(2006) * \\
\end{array}$ & $\begin{array}{l}-3.688048 \\
(2014) * *\end{array}$ & & - & -5.34 & -4.93 & -4.58 \\
\hline EC & $\begin{array}{c}-6.289674 \\
(2010) \\
\end{array}$ & $\begin{array}{c}-7.155943 \\
(2012) \\
\end{array}$ & $\begin{array}{l}-5.942081 \\
(2010)^{* * *} \\
\end{array}$ & $\begin{array}{l}-6.866678 \\
(2012)^{* * *}\end{array}$ & -5.57 & -5.08 & -4.82 \\
\hline TO & $\begin{array}{l}-8.061211 \\
(1999) * * *\end{array}$ & $\begin{array}{l}-7.863766 \\
(1999) * * * \\
\end{array}$ & - & - & -5.57 & -5.08 & -4.82 \\
\hline FD & $\begin{array}{l}-3.642614 \\
(1999) * * *\end{array}$ & $\begin{array}{l}-4.181533 \\
(1999)^{* *}\end{array}$ & - & - & -5.34 & -4.93 & -4.58 \\
\hline POP & $\begin{array}{l}-7.967528 \\
(1999) * * *\end{array}$ & $\begin{array}{c}-7.776862 \\
(1999) * *\end{array}$ & - & - & -5.34 & -4.93 & -4.58 \\
\hline $\mathrm{CO}_{2}$ & $\begin{array}{c}-3.455754 \\
(2004)\end{array}$ & $\begin{array}{c}-3.146150 \\
(2006)\end{array}$ & $\begin{array}{l}-5.323842 \\
(2003) * * *\end{array}$ & $\begin{array}{c}-4.604411 \\
(2015)^{*}\end{array}$ & -5.34 & -4.93 & -4.58 \\
\hline
\end{tabular}

Notes: $* * *, * *$ and $*$ indicate $1 \%, 5 \%$ and $10 \%$ significance levels, correspondingly.

Zivot-Andrews' (1992) critical values were used for the ZA test.

As seen in the ZA test results, it was concluded that while the $\mathrm{CO}_{2}$ and energy consumption (EC) variables were stationary I(1), the GPD, GDP ${ }^{2}$, trade openness, financial development, and population variables were stationary $\mathrm{I}(0)$ ) at the level. It has been determined that Model $\mathrm{C}$ is suitable for $\mathrm{CO}_{2}$ and GDP variables and Model A is suitable for GDP2, TO, FD, POP, and EC variables. The fact that the test statistic is greater than the critical values means that the $\mathrm{H} 0$ hypothesis, which argues that the series contains a unit root without a structural break, is rejected. Therefore, the break dates do not have a permanent effect on the relevant variables.

In the study, a randomly selected lag interval containing the selected variables to determine the lag delay interval, and a Vector Auto-Regressive (VAR) model to scrutinise the lag interval were determined. The lag interval test results obtained are shown in Table 4. 
Table 4: VAR Lag Order Selection Criteria

356

357

358

359

360

361

362

363

364

365

366

367

368

369

370

371

372

373

\begin{tabular}{|c|c|c|c|c|c|c|}
\hline Lag & LogL & LR & FPE & AIC & SC & HQ \\
\hline 0 & 324.7306 & NA & $7.48 \mathrm{e}-21$ & -26.47755 & $-26.13396^{*}$ & -26.38640 \\
\hline 1 & 394.5348 & $93.07217 *$ & $1.59 \mathrm{e}-21$ & -28.21123 & -25.46244 & -27.48198 \\
\hline 2 & 477.1100 & 61.93141 & $\mathbf{3 . 6 6 e - 2 2 *}$ & $\mathbf{- 3 1 . 0 0 9 1 7} *$ & -25.85518 & $\mathbf{- 2 9 . 6 4 1 8 1 *}$ \\
\hline
\end{tabular}

* Specifies lag order selected by the criterion

LR: sequential modified LR test statistic (each test at 5\% level)

FPE: Final prediction error

AIC: Akaike information criterion

SC: Schwarz information criterion

HQ: Hannan-Quinn information criterion

As seen in Table 4, the appropriate lag length to be used to test the cointegration was chosen as $\mathrm{VAR}=2$, because the appropriate lag length was decided as 2 since three different criteria point in this direction. In addition, AIC (Akaike Information Criteria), SC (Schwartz's Criterion) and HQC (Hannan-Quinn information criterion) information criteria were used to find the optimal lag lengths for the ARDL bounds test used for the cointegration connection between the 6 variables included in the study. AIC helps in selecting the maximum possible delay length, while SBC assists in selecting the minimum possible delay length. Table 5 shows the model summaries in the lag order selection criteria.

\section{Table 5: Model Selection Summary}

\begin{tabular}{|l|c|c|c|}
\hline Model & AIC & SC & HQC \\
\hline $2,2,2,2,2,2,2$ & $\mathbf{- 5 . 4 6 7 9 7 5}$ & -4.437178 & $\mathbf{- 5 . 1 9 4 5 0 4}$ \\
\hline $1,1,0,0,2,0,0$ & -5.065364 & -4.533092 & -4.912089 \\
\hline $2,2,2,0,1,0,0$ & -5.315414 & -4.637978 & -5.120337 \\
\hline
\end{tabular}

* Denotes lag order selected by the criterion.

As shown in Table 5 the lag length was selected as Model 2, 2, 2, 2, 2, 2,2 because it had the lowest AIC and HQC values. The Bounds Test results for the longterm relationship are presented in Table 6 . 
Table 6: Bounds Test and Long-term Coefficients for the ARDL Model

\begin{tabular}{|l|c|c|c|c|}
\hline $\mathbf{k = 6}$ & \multicolumn{2}{|c|}{ Case II } & \multicolumn{2}{c|}{ Case III } \\
\hline F-statistic & \multicolumn{2}{|c|}{$11.642600 * * *$} & \multicolumn{2}{c|}{$6.642600 * * *$} \\
\hline Narayan Level & $\mathbf{I}(\mathbf{0})$ & $\mathbf{I}(\mathbf{1})$ & $\mathbf{I}(\mathbf{0})$ & $\mathbf{I}(\mathbf{1})$ \\
\hline $\mathbf{1 0 \%}$ & 1.99 & 2.94 & 1.99 & 2.94 \\
\hline $\mathbf{5 \%}$ & 2.27 & 3.28 & 2.27 & 3.28 \\
\hline $\mathbf{1 \%}$ & 2.88 & 3.99 & 2.88 & 3.99 \\
\hline Pesaran et al. (2001) Level & $\mathbf{I}(\mathbf{0})$ & $\mathbf{I}(\mathbf{1})$ & $\mathbf{I}(\mathbf{0})$ & $\mathbf{I}(\mathbf{1})$ \\
\hline $\mathbf{1 0 \%}$ & 2.25 & 3.38 & -2.57 & -3.86 \\
\hline $\mathbf{5 \%}$ & 2.68 & 3.96 & -2.86 & -4.19 \\
\hline $\mathbf{1 \%}$ & 3.71 & 5.32 & -3.43 & -4.79 \\
\hline
\end{tabular}

*** shows significant at 1\% level. significant at the $1 \%$ significance level for Case II and III. Since the F statistic is 388 larger than the low critical values, the null hypothesis is rejected and the existence of 389 cointegration is confirmed. The estimated long-term coefficients are displayed in 390 Table 7.

Table 7: Long-term Coefficients for the ARDL Model

\begin{tabular}{|c|c|c|l|c|c|}
\hline Variables & Coefficient & t- statistics & Diagnostic Test & F-statistics & P value \\
\hline InGDP & $-1.7596^{* *}$ & -3.1083 & BG-LM Test & 0.9349 & 0.4531 \\
\hline InGDP $^{\mathbf{2}}$ & $0.2879^{* *}$ & -3.1342 & $\begin{array}{l}\text { Ramsey Reset } \\
\text { Test }\end{array}$ & 0.0852 & 0.7743 \\
\hline InEC & $1.0657^{* * *}$ & 6.5665 & F Statistics & 4.9112 & 0.003 \\
\hline InT0 & $-0.7163^{* *}$ & -2.2967 & Jarque-Bera & 0.3208 & 0.851 \\
\hline InFD & $-0.0220^{* * *}$ & -3.4218 & White Test & 1.344051 & 0.3616 \\
\hline InPOP & $4.2365^{* *}$ & 2.0389 & $\begin{array}{l}\text { Model Standard } \\
\text { Deviation }\end{array}$ & 0.0284 \\
\hline C & 0.0024 & 0.6024 & $\begin{array}{l}\text { Durbin Watson } \\
\text { Value }\end{array}$ & \multicolumn{2}{|l}{1.9597} \\
\hline
\end{tabular}


Notes: $* * *, * *$ and $*$ indicate $1 \%, 5 \%$ and $10 \%$ significance levels, correspondingly.

In the long-term ARDL model estimated in Table 7, energy consumption, and population raise $\mathrm{CO}_{2}$ emissions while GDP, financial development and trade openness decreases $\mathrm{CO}_{2}$ emissions in the long run. Additionally, the GDP coefficient was found to be -1.7596 in the model and $\beta_{1}>0$. The GDP $^{2}$ coefficient was 0.2879 , and according to the EKC hypothesis, $\beta_{1}<0$. This indicates that the EKC is valid up to a certain income level in the Russian Federation, and when this income level is exceeded, a positive relationship will begin between economic growth and environmental degradation. It has been determined that there is a positive relationship between energy consumption and population and environmental pollution. $1 \%$ increase in energy consumption and population increases environmental pollution by $1.06 \%$ and $4.23 \%$, respectively. In addition, there is a negative relationship between financial development and trade openness on environmental pollution. A $1 \%$ increase in financial development and trade openness reduces environmental pollution by $0.02 \%$ and $0.71 \%$, respectively.

Two lag lengths are used in the estimated ARDL model. The autocorrelation 410 problem was determined by the Breusch-Godfrey Serial Correlation LM Test and by 411 the Ramsey-Reset test that the model had an appropriate functional form. The Jarque412 Bera test showed that the error terms are normally distributed. Another step related to 413 the ARDL cointegration test is the short-term analysis of the established model and 414 the values related to the created model are reported in Table 8.

Table 8: Short-term ARDL Error Correction Model

\begin{tabular}{|c|c|c|c|c|c|}
\hline Variables & Coefficient & t- statistics & Variables & Coefficient & t- statistics \\
\hline$\triangle I n G D P$ & $-5.2290 * *$ & -4.1147 & $\triangle I n F D$ & 0.0323 & 0.7586 \\
\hline$\Delta I n G D P_{t-1}$ & $2.7458 * *$ & 3.5028 & $\Delta I n F D_{t-1}$ & $0.1315^{* *}$ & 3.0008 \\
\hline$\triangle I n G D P^{2}$ & $0.2751 * *$ & 4.1839 & $\Delta I n T O$ & $-0.0505^{* *}$ & -4.1040 \\
\hline$\Delta I n G D P_{t-1}^{2}$ & $-0.1398 * *$ & -3.4958 & $\Delta I n T O_{t-1}$ & $0.02839^{*}$ & 3.2787 \\
\hline$\triangle I n E C$ & $0.8514 * * *$ & 6.9870 & $\triangle I n P O P$ & -15.1608 & -2.2284 \\
\hline$\Delta I n E C_{t-1}$ & $-1.1929 * *$ & -3.6214 & $\triangle I n P O P_{t-1}$ & $23.0065^{* *}$ & 3.0630 \\
\hline$E C T_{t-1}$ & $-0.7682 * * *$ & -6.6183 & $\mathbf{R}^{2}$ & \multicolumn{2}{|c|}{0.97} \\
\hline
\end{tabular}


Notes: $* * *, * *, *$ denote $1 \%, 5 \%$ and $10 \%$ significance levels, correspondingly.

$$
\begin{gathered}
E C T_{t-1}=\operatorname{InCO}_{2}-1.7596 x \operatorname{InGDP}+0.0879 x \operatorname{InGDP} P^{2}-1.0657 x \operatorname{In} E C-0.0221 x \operatorname{In} F D \\
-0.7163 x \operatorname{InTO}+4.2365 x \operatorname{In} P O P+0.0025
\end{gathered}
$$

As seen in Table 7, it is seen that the test statistics for the model are appropriate. An important issue in short-term analysis is the error correction term. The error correction term should generally have a statistical value between "0" and "-1".

423 The error correction term of the established model is statistically significant and was

424 found to be -0.7682 . In other words, $97 \%$ of short-term deviations are corrected in the next period.

Finally, CUSUM and CUSUMQ tests were conducted to test the stability of the ARDL model and its long-run coefficients, in other words, to provide information about the incidence of structural breaks in the data set in general. CUSUM test indicates whether there is a structural break or not and CUSUMQ indicates the period of the break (Doguwa et al., 2014: 20). The interpretation of the related tests is that the curves obtained with the error terms test statistics are within the critical limits and if they are, the estimated parameters are stable. Figure 2 shows the CUSUM and CUSUMQ test charts.

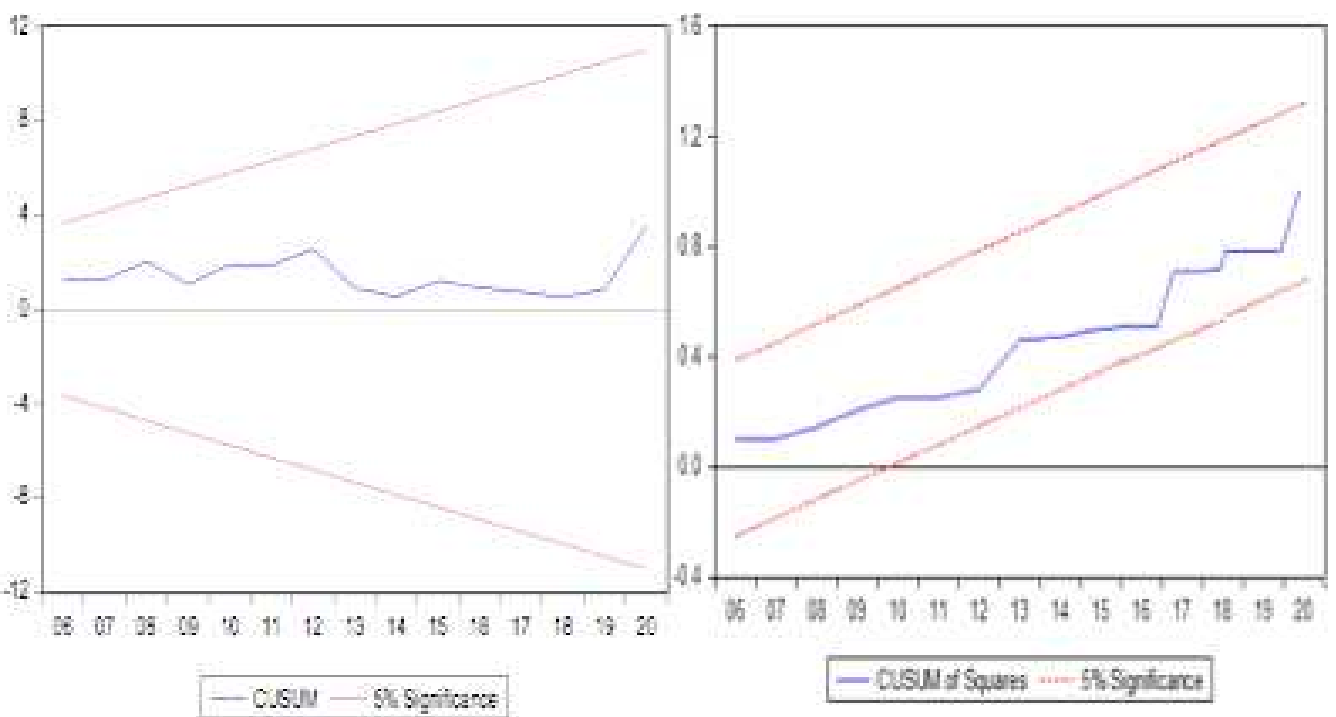
Figure 2: CUSUM and CUSUMQ Plots for the ARDL Model

As seen in the CUSUM and CUSUMQ graphs, the fact that the curves are within the critical value band at the 5\% significance level indicates that there are no structural breaks in the determined long-term relationship, and it can be interpreted that the parameters are significant. Furthermore, the outcomes of the CUSUM and CUSUMSQ tests show that the coefficients in the two ARDL models are stable. 


\section{Conclusion and Policy Implications}

In this study, the acceptability of the EKC for the economy of the Russian

444 Federation was tested with the 1990-2020 period data. In this framework, the ARDL

445 cointegration test was applied within the framework of a quadric model. It was

446 determined that the coefficients of the GDP, GDP ${ }^{2}$ variables, which were taken into account to test the EKC hypothesis, were statistically significant.

According to findings, energy consumption, financial development, trade openness, population, GDP and its square are the most significant indicators of $\mathrm{CO}_{2}$ emissions in the long term. A $1 \%$ raises energy consumption and population increases $\mathrm{CO}_{2}$ emissions by $1.0657 \%$ and $4.2365 \%$, correspondingly. A $1 \%$ increases in GDP, financial development and trade openness decreases $\mathrm{CO}_{2}$ emissions by $1.7596 \%$, $0.0220 \%$ and $0.7163 \%$, correspondingly.

The analysis findings of the study showed the existence of a U-shaped link between economic development and $\mathrm{CO}_{2}$ emissions, which does not approve the acceptability of the EKC hypothesis in the long term for the Russian Federation. It was determined that the coefficients of the GDP, GDP ${ }^{2}$, variables, which were taken into account to test the EKC hypothesis, were statistically significant. However, it is seen that the relevant variables are marked (-), (+) respectively. This situation is not in

460 line with the EKC and expresses a " $\mathrm{U}$ " link between the environment and economic 461 growth. The same findings were obtained by Gavrilyeva et al. (2020) indicates that 462 EKC hypothesis is not acceptable for Russian Federation. Furthermore, Rudenko and 463 Skripnuk (2016) ensure little evidence to support the existence of EKC for the 464 Russian Arctic areas. The contrary of a finding of Sohag et al. (2021), Burakov 465 (2019), Bass et al. (2019), Ketenci (2018), Yang et al. (2017) find that EKC is valid 466 for the Russian Federation. Among the studies conducted for BRICS countries, Aydin 467 and Turan (2020) found that the EKC hypothesis is not valid for Russian Federation, 468 but Ummalla and Goyari (2021), Ferreira et al. (2021), Erataş and Uysal (2014) find that EKC is acceptable for BRICS countries, as well Russian Federation.

The EKC hypothesis is valid up to a certain income level in the Russian

471 Federation, and when this income level is exceeded, a positive relationship between 472 economic growth and environmental degradation is predicted. While this is a positive 473 result for the first stages of economic growth, it is an unacceptable result for the 
advanced stages of economic growth within the framework of the EKC hypothesis. In the short-term relationship of the model established for the analysis, it is seen that the error correction mechanism works and its coefficient is statistically and significant. Most of the short-term deviations are corrected in the next period.

The other independent variable used in the study, energy consumption, has a significant effect on the findings. There is a positive and strong relationship between $\mathrm{CO} 2$ emissions and energy consumption. The increase in energy consumption increases $\mathrm{CO} 2$ emissions. While fossil-based energy sources are mostly used in energy consumption for the Russian Federation, the use of renewable energy is very 483 limited.

In the scope of the obtained findings, some policy recommendations can be made for the Russian Federation. The Russian Federation should prefer the use of clean energy (renewable, nuclear, etc.) instead of fossil energy resources to decrease $\mathrm{CO}_{2}$ emissions. In addition, various energy sources should be used in order to expansion the share of energy sources that do not emit carbon in total energy consumption and to increase energy use efficiency through advanced technologies. There is strong evidence that energy use has a devastating impact on $\mathrm{CO}_{2}$ emissions, and financial development encouragingly influences ecological quality in the long term. Thus, policymakers should apply appropriate strategies concerning financial development.

The current study is important both in terms of national economy and environmental quality. Therefore, in future studies, it is essential to evaluate the issue from different dimensions with additional variables or to compare the current situation with other countries in order to reveal the effects of the policy applied and the changes made for the geography.

Furthermore, EKC hypothesis concentrated on the rise in the production level due to the economies of scale, together with the economic development, causes fast ecological pollution. When the income reaches a certain point, the process enters the recovery process (Dinda, 2004). However, this study found the relationship between

$503 \mathrm{CO} 2$ and income in a " $U$ " shape. Therefore, future studies will focus on the question 504 of "What needs to be done for the CKE hypothesis to be valid for the Russian Federation?" 
507 Ethics approval and consent to participate

508 Not Applicable.

509

510 Consent for publication

511 Not Applicable.

512

513

Authors Contributions

514 Material preparation, data collection and analysis were performed by Nurcan Kilinc-

515 Ata and Vladimir L. Likhachev.

516

517 Funding

518 There is no any funding for this paper.

519

520 Competing interests

521 The author declares that there are no competing interests.

522

523

\section{Availability of data and materials}

524 The datasets used and/or analyzed during the current study are available from the 525 corresponding author on reasonable request.

526

527 
Abdallh, A. A., \& Abugamos, H. (2017). A semi-parametric panel data analysis on the urbanisation-carbon emissions nexus for the MENA countries. Renewable and Sustainable Energy Reviews, 78, 1350-1356.

AlZgool, M. R. H., Shah, S. M. M., \& Ahmed, U. (2020). Impact of Energy consumption and Economic Growth on Environmental Performance:

Akpan, G. E., \& Akpan, U. F. (2012). Electricity consumption, carbon emissions and economic growth in Nigeria. International Journal of Energy Economics and Policy, 2(4), 292.

Al-Rawashdeh, R., Jaradat, A. Q., \& Al-Shboul, M. (2014). Air pollution and economic growth in MENA countries: testing EKC hypothesis. Environmental Research, Engineering and Management, 70(4), 54-65. study of Bangladesh. International Review of Applied Economics, 17(1), 85-103.

Alam, I., \& Quazi, R. (2003). Determinants of capital flight: An econometric case

Alsamara, M., Mrabet, Z., Saleh, A. S., \& Anwar, S. (2018). The environmental

Alege, P. O., Adediran, O. S., \& Ogundipe, A. A. (2016). Pollutant emissions, energy consumption and economic growth in Nigeria. International Journal of Energy Economics and Policy, 6(2), 202-207.

Allard, A., Takman, J., Uddin, G. S., \& Ahmed, A. (2018). The N-shaped environmental Kuznets curve: an empirical evaluation using a panel quantile regression approach. Environmental Science and Pollution Research, 25(6), 5848-5861.

Amri, F. (2018). Carbon dioxide emissions, total factor productivity, ICT, trade, financial development, and energy consumption: testing environmental Kuznets curve hypothesis for Tunisia. Environmental Science and Pollution Research, 25(33), 33691-33701. 
Ansari, M. A., Ahmad, M. R., Siddique, S., \& Mansoor, K. (2020). An environment Kuznets curve for ecological footprint: Evidence from GCC countries. Carbon Management, 11(4), 355-368.

Aydin, M., \& Turan, Y. E. (2020). The influence of financial openness, trade openness, and energy intensity on ecological footprint: revisiting the environmental Kuznets curve hypothesis for BRICS countries. Environmental Science and Pollution Research, 27(34), 43233-43245.

Baek, J. (2015). Environmental Kuznets curve for $\mathrm{CO}_{2}$ emissions: the case of Arctic countries. Energy Economics, 50, 13-17.

Balado-Naves, R., Baños-Pino, J. F., \& Mayor, M. (2018). Do countries influence neighbouring pollution? A spatial analysis of the $\mathrm{EKC}$ for $\mathrm{CO}_{2}$ emissions. Energy Policy, 123, 266-279.

Balaguer, J., \& Cantavella, M. (2016). Estimating the environmental Kuznets curve for Spain by considering fuel oil prices (1874-2011). Ecological Indicators, 60, 853-859.

Balsalobre-Lorente, D., Shahbaz, M., Jabbour, C. J. C., \& Driha, O. M. (2019). The role of energy innovation and corruption in carbon emissions: Evidence based on the EKC hypothesis. In Energy and environmental strategies in the era of globalization (pp. 271-304). Springer, Cham.

Bass, A. (2019). Does financial development matter for environmental Kuznets Curve in Russia?: evidence from the autoregressive distributed lag bounds test approach. International Journal of Energy Economics and Policy (IJEEP), 9(4): 334-341.

Beck, K. A., \& Joshi, P. (2015). An analysis of the environmental Kuznets curve for carbon dioxide emissions: evidence for OECD and Non-OECD countries. European Journal of Sustainable Development, 4(3), 33-33.

Begum, R. A., Sohag, K., Abdullah, S. M. S., \& Jaafar, M. (2015). CO 2 emissions, energy consumption, economic and population growth in Malaysia. Renewable and Sustainable Energy Reviews, 41, 594-601.

Bento, J. P. C., \& Moutinho, V. (2016). $\mathrm{CO}_{2}$ emissions, non-renewable and renewable electricity production, economic growth, and international trade in Italy. Renewable and Sustainable Energy Reviews, 55, 142-155. 
Brown, S. P., \& McDonough, I. K. (2016). Using the Environmental Kuznets Curve to evaluate energy policy: Some practical considerations. Energy Policy, 98, 453-458.

Brown, R. L., Durbin, J., \& Evans, J. M. (1975). Techniques for testing the constancy of regression relationships over time. Journal of the Royal Statistical Society: Series B (Methodological), 37(2), 149-163.

Burakov, D. (2019). Does agriculture matter for environmental Kuznets curve in Russia: evidence from the ARDL bounds tests approach. Agris on-line Papers in Economics and Informatics, 11(665-2019-4012), 23-34.

Cheikh, N. B., Zaied, Y. B., \& Chevallier, J. (2021). On the nonlinear relationship 602 between energy use and $\mathrm{CO}_{2}$ emissions within an EKC framework: Evidence from panel smooth transition regression in the MENA region. Research in International Business and Finance, 55, 101331. renewable and non-renewable energy production and foreign trade in China. Renewable energy, 131, 208-216.

Chen, Y., Wang, Z., \& Zhong, Z. (2019). CO 2 emissions, economic growth,

Climate Transparency, (2020). Climate Transparency Report. https://www.climatetransparency.org/wp-content/uploads/2020/11/Russia-CT-2020-WEB.pdf, Acessed Date: 08.11.2021.

Cowan, W. N., Chang, T., Inglesi-Lotz, R., \& Gupta, R. (2014). The nexus of electricity consumption, economic growth and $\mathrm{CO}_{2}$ emissions in the BRICS countries. Energy Policy, 66, 359-368.

Cruz Rios, F., Naganathan, H., Chong, W. K., Lee, S., \& Alves, A. (2017). Analyzing the impact of outside temperature on energy consumption and production patterns in high-performance research buildings in Arizona. Journal of Architectural Engineering, 23(3), C4017002.

Culas, R. J. (2007). Deforestation and the environmental Kuznets curve: An 624 institutional perspective. Ecological Economics, 61(2-3), 429-437.

Dickey, D. A., \& Fuller, W. A. (1979). Distribution of the estimators for autoregressive time series with a unit root. Journal of the American statistical association, 74(366a), 427-431.

Dinda, S. (2004). Environmental Kuznets curve hypothesis: a survey. Ecological economics, 49(4), 431-455. 

Structural breaks, cointegration and demand for money in Nigeria. CBN Journal of Applied Statistics (JAS), 5(1): 15-33.

Engle, R. F., \& Granger, C. W. (1987). Co-integration and error correction: representation, estimation, and testing. Econometrica: journal of the Econometric Society, 251-276.

Erataş, F., \& Uysal, D. (2014). Çevresel Kuznets Eğrisi Yaklaşımının "Brıct" Ülkeleri Kapsamında Değerlendirilmesi. İstanbul Üniversitesi Iktisat Fakültesi Mecmuası, 64(1), 1-25.

Erdogan, S., Okumus, I., \& Guzel, A. E. (2020). Revisiting the Environmental Kuznets Curve hypothesis in OECD countries: the role of renewable, nonrenewable energy, and oil prices. Environmental Science and Pollution Research, 27(19), 23655-23663.

Farhani, S., \& Ozturk, I. (2015). Causal relationship between CO 2 emissions, real GDP, energy consumption, financial development, trade openness, and urbanization in Tunisia. Environmental Science and Pollution Research, 22(20), 15663-15676.

Ferreira, E., Fuinhas, J. A., \& Moutinho, V. (2021). An investigation of the environmental Kuznets relationship in BRICS countries at a sectoral economic level. Energy Systems, 1-24.

Friedl, B., \& Getzner, M. (2003). Determinants of $\mathrm{CO}_{2}$ emissions in a small open economy. Ecological economics, 45(1), 133-148.

Gavrilyeva, T., Sugimoto, A., Bochkarev, N., Stepanova, N., Nogovitcyn, A., \& Semenova, L. (2020). Economy-related green-house gases emissions and validation of the environmental Kuznets curve for Sakha Republic (Yakutia). Polar Science, 23, 100507. American free trade agreement. National Bureau of Economic Research. Working Paper 3914. 
Hanif, I. (2018). Impact of economic growth, non-renewable and renewable energy consumption, and urbanization on carbon emissions in Sub-Saharan Africa. Environmental Science and Pollution Research, 25(15), 15057-15067.

Haseeb, A., Xia, E., Baloch, M. A., \& Abbas, K. (2018). Financial development, globalization, and $\mathrm{CO} 2$ emission in the presence of EKC: evidence from BRICS countries. Environmental Science and Pollution Research, 25(31), 31283-31296.

Hsu, P. H., Tian, X., \& Xu, Y. (2014). Financial development and innovation: Cross-country evidence. Journal of financial economics, 112(1), 116-135. (2021). The increases and decreases of the environment Kuznets curve (EKC) for 8 OECD countries. Environmental Science and Pollution Research, 28(22), 28535-28543.

Iwata, H., Okada, K., \& Samreth, S. (2012). Empirical study on the determinants of $\mathrm{CO}_{2}$ emissions: evidence from OECD countries. Applied Economics, 44(27), 3513-3519.

Johansen, S., \& Juselius, K. (1990). Maximum likelihood estimation and inference on cointegration - with appucations to the demand for money. Oxford Bulletin of Economics and statistics, 52(2), 169-210.

682 development on the environment in China: a cointegration analysis. fi33(2), 284-291.

Jamel, L., \& Maktouf, S. (2017). The nexus between economic growth, financial development, trade openness, and $\mathrm{CO}_{2}$ emissions in European countries. Cogent Economics \& Finance, 5(1), 1341456. Murshed, M. (2021). Do natural gas, oil, and coal consumption ameliorate Science and Pollution Research, 1-17. 
Karaca, C. (2012). Ekonomik Kalkınma ve Çevre Kirliliği İlişkisi: Gelişmekte Olan Ülkeler Üzerine Ampirik Bir Analiz. Journal of the Çukurova University Institute of Social Sciences, 21(3): 139-156.

Ketenci, N. (2018). The environmental Kuznets curve in the case of Russia. Russian Journal of Economics, 4, 249-265.

Koc, S., \& Bulus, G. C. (2020). Testing validity of the EKC hypothesis in South Korea: role of renewable energy and trade openness. Environmental Science and Pollution Research, 27(23), 29043-29054.

Lantz, V., \& Feng, Q. (2006). Assessing income, population, and technology impacts on $\mathrm{CO}_{2}$ emissions in Canada: where's the EKC? Ecological Economics, 57(2), 229-238.

Leal, P. H., \& Marques, A. C. (2020). Rediscovering the EKC hypothesis for the 20 highest $\mathrm{CO}_{2}$ emitters among OECD countries by level of globalization. International Economics, 164, 36-47.

Liu, Y., Zhou, Y., \& Wu, W. (2015). Assessing the impact of population, income and technology on energy consumption and industrial pollutant emissions in China. Applied Energy, 155, 904-917.

Mahmood, H., Maalel, N., \& Zarrad, O. (2019). Trade openness and $\mathrm{CO}_{2}$ emissions: Evidence from Tunisia. Sustainability, 11(12), 3295.

Marshintsev, V., \& Gadiyatov, V. (2021). Yakutia as One of the Richest in Natural Resources Regions of the Russian Federation. Earth, 10(3), 90-94.

Narayan, P. K., \& Smyth, R. (2006). What determines migration flows from low income to high - income countries? An empirical investigation of Fiji-Us migration 1972-2001. Contemporary economic policy, 24(2), 332-342.

Nasir, M. A., Huynh, T. L. D., \& Tram, H. T. X. (2019). Role of financial development, economic growth \& foreign direct investment in driving climate change: A case of emerging ASEAN. Journal of environmental management, 242, 131-141.

Nkoro, E., \& Uko, A. K. (2016). Autoregressive Distributed Lag (ARDL) cointegration technique: application and interpretation. Journal of Statistical and Econometric methods, 5(4), 63-91. 
Ozatac, N., Gokmenoglu, K. K., \& Taspinar, N. (2017). Testing the EKC hypothesis by considering trade openness, urbanization, and financial development: the case of Turkey. Environmental Science and Pollution Research, 24(20), 16690-16701.

Ozcan, B. (2013). The nexus between carbon emissions, energy consumption and economic growth in Middle East countries: a panel data analysis. Energy Policy, 62, 1138-1147.

Pao, H. T., \& Tsai, C. M. (2010). $\mathrm{CO}_{2}$ emissions, energy consumption and economic growth in BRIC countries. Energy policy, 38(12), 7850-7860. energy consumption, and economic growth in Brazil. Energy, 36(5), 24502458.

Pao, H. T., Yu, H. C., \& Yang, Y. H. (2011). Modeling the $\mathrm{CO}_{2}$ emissions, energy use, and economic growth in Russia. Energy, 36(8), 5094-5100.

Pesaran, M. H., Shin, Y., \& Smith, R. J. (2001). Bounds testing approaches to the analysis of level relationships. Journal of applied econometrics, 16(3), 289326.

Rudenko, D., \& Skripnuk, D. (2016). Environmental Kuznets curve: The case of arctic Russian regions. International Multidisciplinary Scientific GeoConference: SGEM, 3, 209-216.

Rustemoglu, H., \& Andrés, A. R. (2016). Determinants of $\mathrm{CO}_{2}$ emissions in Brazil and Russia between 1992 and 2011: A decomposition analysis. Environmental Science \& Policy, 58, 95-106.

Saint Akadiri, S., Alola, A. A., Bekun, F. V., \& Etokakpan, M. U. (2020). Does electricity consumption and globalization increase pollutant emissions? Implications for environmental sustainability target for China. Environmental Science and Pollution Research, 27(20), 25450-25460.

Salahuddin, M., \& Gow, J. (2014). Economic growth, energy consumption and $\mathrm{CO}_{2}$ emissions in Gulf Cooperation Council countries. Energy, 73, 44-58.

Salari, M., Javid, R. J., \& Noghanibehambari, H. (2021). The nexus between $\mathrm{CO}_{2}$ emissions, energy consumption, and economic growth in the US. Economic Analysis and Policy, 69, 182-194. 
Salim, R., Rafiq, S., Shafiei, S., \& Yao, Y. (2019). Does urbanization increase pollutant emission and energy intensity? Evidence from some Asian developing economies. Applied Economics, 51(36), 4008-4024.

Sekrafi, H., \& Sghaier, A. (2018). Examining the relationship between corruption, economic growth, environmental degradation, and energy consumption: a panel analysis in MENA region. Journal of the Knowledge Economy, 9(3), 963-979.

Shahbaz, M., Tiwari, A. K., \& Nasir, M. (2013a). The effects of financial development, economic growth, coal consumption and trade openness on $\mathrm{CO}_{2}$ emissions in South Africa. Energy Policy, 61, 1452-1459.

Shahbaz, M., Solarin, S. A., Mahmood, H., \& Arouri, M. (2013b). Does financial development reduce $\mathrm{CO}_{2}$ emissions in Malaysian economy? A time series analysis. Economic Modelling, 35, 145-152.

Shumkov, A. (2010). The Russian Federation Before and After the Soviet Union, Russia in Global Affairs, 8(3), 7-17.

Sohag, K., Mariev, O., \& Davidson, N. (2021). Revising environmental Kuznets curve in Russian regions: role of environmental policy stringency. Environmental Science and Pollution Research, 1-14.

Svirydzenka, K. (2016). Introducing a new broad-based index of financial development. International Monetary Fund.

Ummalla, M., \& Goyari, P. (2021). The impact of clean energy consumption on economic growth and $\mathrm{CO}_{2}$ emissions in BRICS countries: Does the environmental Kuznets curve exist?. Journal of Public Affairs, 21(1), e2126.

\section{UNCTAD World Investment Report,}

(2021). https://unctad.org/system/files/official-document/wir2021_en.pdf, Access Date: 17.12.2021.

Yang, X., Lou, F., Sun, M., Wang, R., \& Wang, Y. (2017). Study of the relationship between greenhouse gas emissions and the economic growth of Russia based on the Environmental Kuznets Curve. Applied energy, 193, 162-173.

Yang, G., Sun, T., Wang, J., \& Li, X. (2015). Modeling the nexus between carbon dioxide emissions and economic growth. Energy Policy, 86, 104-117. 
Yoo, S. H. (2005). Electricity consumption and economic growth: evidence from Korea. Energy policy, 33(12), 1627-1632.

Youssef, A. B., Boubaker, S., \& Omri, A. (2020). Financial development and macroeconomic sustainability: modeling based on a modified environmental Kuznets curve. Climatic Change, 163(2), 767-785.

Yusuf, A. M., Abubakar, A. B., \& Mamman, S. O. (2020). Relationship between greenhouse gas emission, energy consumption, and economic growth: evidence from some selected oil-producing African countries. Environmental science and pollution research international, 27(13), 15815.

Wang, S. X., Fu, Y. B., \& Zhang, Z. G. (2015). Population growth and the environmental Kuznets curve. China Economic Review, 36, 146-165.

World Bank, (2021), https://www.theglobaleconomy.com/compare-countries/, Access Date: 15.12.2021.

Zhang, Y. J. (2011). The impact of financial development on carbon emissions: An empirical analysis in China. Energy policy, 39(4), 2197-2203.

803

804

805

806 oil-price shock, and the unit-root hypothesis. Journal of business \& 